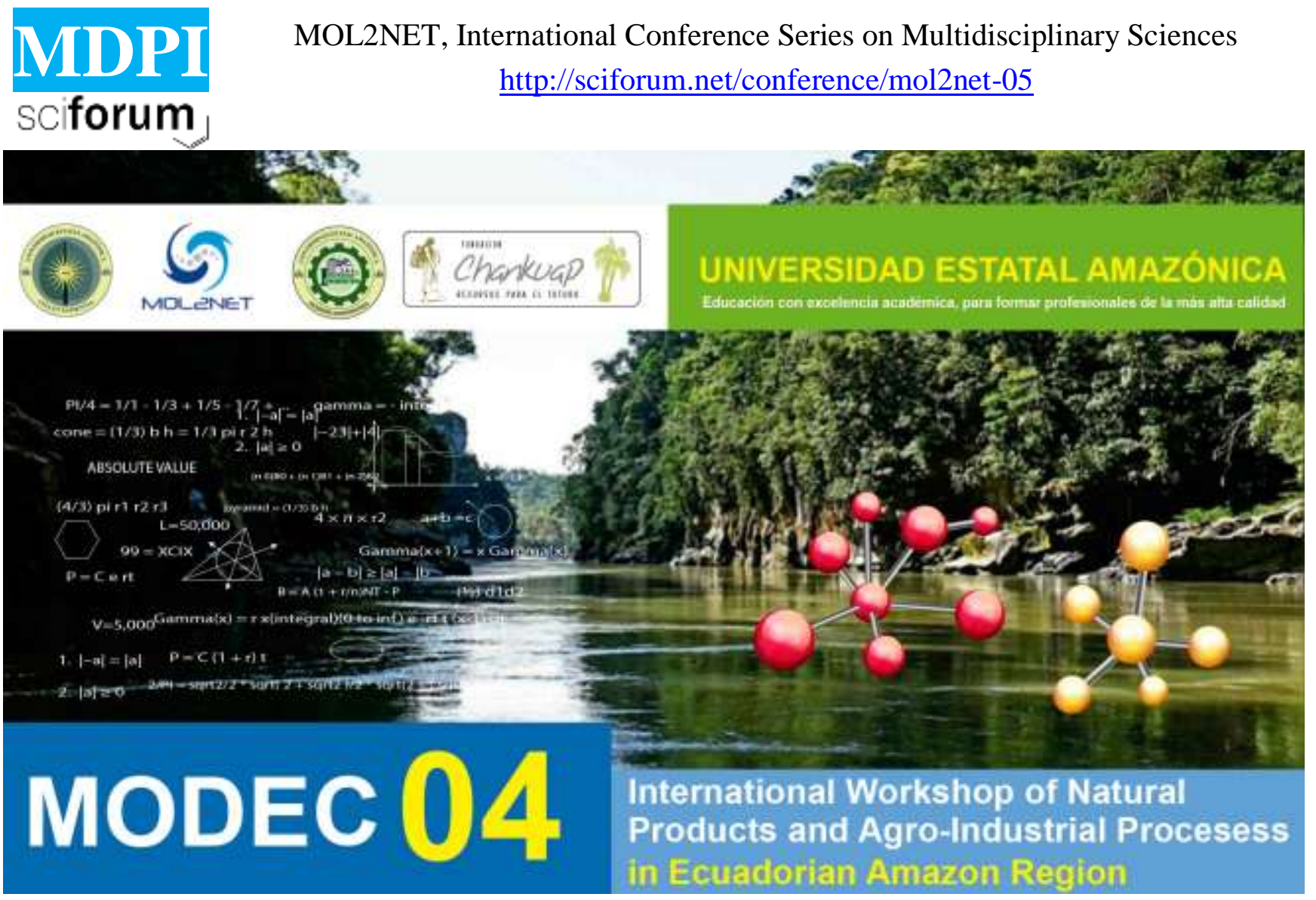

\title{
Apparent digestibility of dry and organic matter in Chinese potato rejection tubers (Colocasia esculenta (L.) Schott) in pigs.
}

Ramírez- Sánchez Alina (aramirez@uea.edu.ec), Viamonte- Garcés, M.I (mviamonte@uea.edu.ec), Caicedo-Quiche Willian Orlando (wcaicedo@uea.edu.ec), Mora- Guaman Stefanny Silvana (agr20140047@uea.edu.ec)

${ }^{a}$ Departamento de Ciencias de la Tierra, Universidad Estatal Amazónica, Puyo, Pastaza, Ecuador

Graphical Abstract

\begin{abstract}
.
The experiment was carried out at the Amazon Research, Postgraduate and Conservation Center (CIPCA) of the Amazon State University, where two levels of substitution of Chinese potato flour in the diet of growing pigs were evaluated for the effect, 3 animals were used castrated males resulting from crossbreeding (Largewhite $\mathrm{x}$ Duroc x Pietrain), with an initial average weight of $25 \mathrm{~kg}$. The animals were placed in 3 metabolic cages and fed a control diet (T1) and two experimental diets T2 $(20 \%)$ and T3 (40\%) of
\end{abstract}




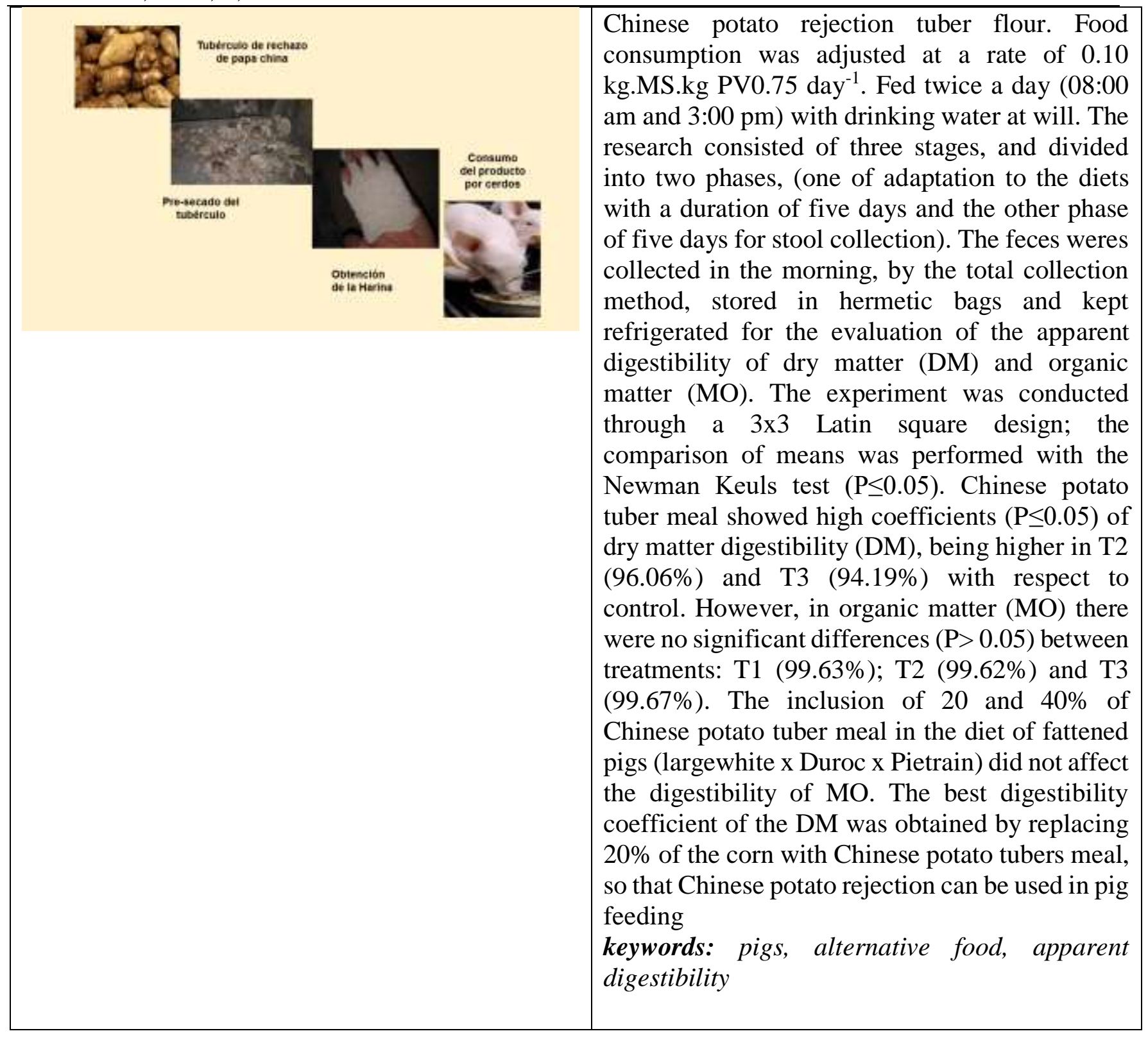

\section{Introduction}

High food consumption and rapid population growth have increased the cost of raw materials used to make balanced diets for monogastric animals (Aragadvay, Núñez, Velastegui, Villacis and Guerrero, 2016); therefore, it is necessary to find alternatives for feeding animals and at the same time does not compete with human food. One of the products that is produced in the Ecuadorian Amazon is precisely the Chinese potato, considered in the pastaza province as the most exploited agricultural crop, which contributes to the strengthening of family economies in the area. According to BanEcuador, (2017) 60\% of the total production is directed to the international market; $20 \%$ represents the second and third quality Chinese potatoes that are marketed in the national market and the remaining $20 \%$ constitutes rejection (GADPPz, 2014).

For the use of Chinese potato rejection, the type and amount of nutrients it provides; as well as the determination of the presence of secondary metabolites that can affect consumption behavior and digestibility must take the nutritional value into account; which is influenced. 


\section{Materials and Methods}

\section{Location}

The experimental work was carried outs in the Swine program of the Amazon Research, Postgraduate and Conservation Center (CIPCA), located on the Puyo - Tena road $44 \mathrm{~km}$ between the Santa Clara and Arosemena Tola cantons of the Pastaza and Napo provinces. It is located in a humid tropical environment, with annual rainfall reaching $4000 \mathrm{~mm}$ with a relative humidity of around $80 \%$ and varying temperatures between 15 to $25^{\circ} \mathrm{C}$.

\section{Experimental procedure}

The method of total stool collection (Caicedo et al., 2017) was used to assess the apparent digestibility of the DM and MO of the diets. In the food and excreta samples the content of MS, MO and ash was determined according to the procedures described by the AOAC (2005). It was considered that the content of organic matter (MO) was the result of subtracting (100\% ash).

For the production of the Chinese potato rejection tuber flour, we worked with the waste generated by the production of this tuber Rural Parish Teniente Hugo Ortiz, Allishungo Community; therefore, the tuber was first washed with a solution of $3 \%$ hypochlorite in water for 10 minutes. Once drained, it was sliced into slices and pre-dried in the sun for 8 hours and dried in an industrial rotary dryer (Burmester brand) at $70^{\circ} \mathrm{C}$ for two hours; once dried, it was ground in an industrial mill and sifted at $0.25 \mathrm{~mm}$, which was packed and stored

To evaluate the digestibility of the Chinese potato rejection tuber, 3 castrated male animals of the genotype fattening category (Largewhite $\mathrm{x}$ Duroc $\mathrm{x}$ Pietrain) were selected with an initial mean weight of $35 \pm 2 \mathrm{~kg}$, which were dewormed and placed in 3 cages metabolic of $0.40 \mathrm{~m} \times 1.50 \mathrm{~m}(0.60 \mathrm{~m} 2)$. The application of the diet began with an adaptation of the food for five days, for each of the treatments and five days for the total stool collection. The treatments were control diet (T1) and two experimental diets T2 and T3 (replacement of 20 and 40\% corn with Chinese potato tuber meal), the three diets adjusted with $17 \%$ crude protein (Rostagno et al., 2011), and formulated according to the recommendations of the (NRC, 2012). As food consumption was adjusted at a rate of 0.10 kg.MS.kg PV0.75 day-1 and fed twice a day, at 08:00 am and 15:00 pm, drinking water was available at will.

The design used was a Latin square ( $3 * 3)$. An ANOVA analysis was applied and the Newman Keuls test, processed by the statistical package SPSS version 22.1, was used for the difference between means.

\section{Results and Discussion}

The Table 1 shows the apparent digestibility of dry matter (MS) and organic matter (MO), in pigs (Largewhite x Duroc x Pietrain) fed with flour from the Chinese potato rejection tuber, replacing corn in 20 and $40 \%$ In the diets provided, significant differences were obtained for dry matter digestibility 
(DM) P <0.0005; where T2 (20\%) presented a dry matter digestibility (MS) of 96.02 higher in 2.78 and 1.87 to those obtained in T1 (control) of 93.28 and T3 (40\%) of 94.14 respectively. The superiority of dry matter digestibility in T2 (20\%) may be related to the low fiber content of the food supplied.

Table 1. Apparent digestibility coefficients of the MS and MO of Chinese potato tuber meal for pigs.

\begin{tabular}{cccccc}
\hline \multirow{2}{*}{ Variables } & \multicolumn{2}{c}{ Inclusion levels of Chinese potato tuber flour, \% } & \multicolumn{2}{c}{ P value } \\
\cline { 2 - 4 } & T1 (control, 0) & T2 (20) & T3 (40) & EE \pm & \\
\hline MS, \% & $93.28^{\mathrm{b}}$ & $96.06^{\mathrm{a}}$ & $94.19^{\mathrm{b}}$ & 0.79 & $\mathrm{P}<0.0005$ \\
MO, \% & 99.63 & 99.62 & 99.67 & 1.30 & $\mathrm{P}=0.5856$ \\
\hline
\end{tabular}

Different letters per row show significant differences according to Newman Keuls P $<0.005$

According to Vargas and Hernández (2012), the digestibility of the flours of some vegetables such as potatoes, cassava and sweet potatoes are related to the omposition of starch (amylose and amylopectin) being more digestible those foods that have starches with low amylose content, being These easily digestible.

Caicedo (2013), indicates digestibility coefficients of DM (66.90\%) in dry tubers and (31.50\%) in fresh tubers of Chinese potatoes without prior treatment; lower than those reported for these results, in the same way, Rodríguez (2003), evaluated the total digestibility of sweet potato or sweet potato foliage, with the incorporation of lipids and zeolite in diets for growing pigs obtaining digestibility coefficients of 79.8 to 88.5 on the other hand, Quintero (2009), obtained digestibility coefficients of the DM of 82.4 and 82.5 when using diets of sweet potato flour and dried cassava. With respect to organic matter (MO), there were no significant differences between treatments T1 (control), T2 (20\%) and T3 (40\%).

\section{Conclusions}

Both of them 20 and $40 \%$ Chinese potatoes rejecting tuber flour showed an apparent high digestibility, so it's can be used in pig feeding. Although the best digestibility was $20 \%$.

\section{References}

1. Aragadvay, R.; Núñez, O., Velástegui, G.; Villacís, L.; y Guerrero, J. 2016. Using Colocasia esculenta L. meal in feed for pigs and its effect on production parameters. Journal of the Selva Animal Science, 17 (2-3),

2. BanEcuador, La Papa China Accede a Mercados Internacionales. 2017. Obtenido de https://www.banecuador.fin.ec: https://www.banecuador.fin.ec/noticias-banecuador/boletines-deprensa/la-papa-china-accede-mercados-internacionales/

3. Caicedo, W. Tubérculos de papa china (Colocasia esculenta (L.) Schott) como una fuente energética tropical para alimentar cerdos. Una reseña corta sobre las características de la composición química y de los factores antinutricionales. Revista Computarizada de Producción Porcina. 20:278-282. 2013. 
4. Caicedo, W., Rodríguez, R., Lezcano, P., Ly, P., Vargas, JC, Uvidia, H., Valle, S. y Flores, L. 2017. Caracterización de antinutrientes en cuatro ensilados de taro (Colocasia esculenta (L.) Schott) para cerdos. Cuban Journal of Agricultural Science, 5 (1-2),

5. Gobierno Autónomo Descentralizado Provincial de la Provincia de Pastaza-GADPPz 2014. Plan Productivo Provincial "Pastaza 2014-2025”. 77 (31).

6. Gobierno Autónomo Descentralizado Provincial de la Provincia de Pastaza -GADPPz. (2016). Dirección de Desarrollo Rural Sustentable-Cadena Productiva de la Papa China 7(4-5).

7. NRC. Nutrient requirements of swine. 2012. 11th ed., Washington, D.C, USA: Natl. Acad. Press., ISBN: 978-0-309-22423-9.

8. Quintero, G., Alimentación de cerdos a base de harina de yuca y batata. 2009. Obtenido de https://www.engormix.com: https://www.engormix.com/porcicultura/articulos/alimentacioncerdos-base-harina-t28257.htm

9. Rodríguez, A., González, E., Díaz, I., Vecchionacce, H., y Hurtado, E. 2003. Efecto de la incorporación de lípidos y zeolita en la digestibilidad total aparente de dietas con follaje de batata (Ipomoea batatas L.) en cerdos. Revista Cubana de Ciencia Agrícola. Tomo 37, No. 4, 2003. 427, 231.

10. Rostagno, H., Teixeira, L., Lopes, D., Gomes, P., De Oliveira, R., Suarez, D., Ferreira, A., De Toledo, S., Euclides, R.. 2011. Tablas brasileñas para aves y cerdos, Composición de Alimentos y Requerimientos Nutricionales. $3^{\text {ra }}$ Edición, Universidad Federal de Viçosa - Departamento de Zootecnia. P 259 (29-31).

11. Vargas, P., Hernández, D. 2012. Harinas y almidones de yuca, ñame, camote y ñampí: propiedades funcionales y posibles aplicaciones en la industria alimentaria. Tecnología en Marcha. Vol. 26, No 1 Pág. 37-45. 